\title{
Delegating Powers in the European Community
}

\author{
FABIO FRANCHINO*
}

\begin{abstract}
The theory of delegation developed by Epstein and O'Halloran for the US federal system is used here to generate original hypotheses on the politics of delegation in the European Community (EC). It is argued that two institutional features of the Community, namely the decision rules of the Council of Ministers and the possibility of relying on both the Commission and the member states for policy implementation are at the core of the choices of delegation of EC legislators. Using an original dataset of 158 major EC legislative acts, it is demonstrated that the Council delegates greater policy authority to national institutions if legislation is adopted unanimously or in issue areas that require specialized and technical knowledge, while it relies to a greater extent on the Commission when acts are adopted by qualified majority voting or require general managerial skills at the supranational level.

Results also show that national administrators are the main providers of policy expertise, while the informational role of the Commission appears to be secondary, though not negligible. Finally, these findings qualify propositions on the relation between veto players and bureaucratic autonomy and on that between conflict within the legislature and delegation outcomes.
\end{abstract}

The comparative study of delegation is rapidly becoming a field of political research where sophisticated theories are developed and tested across political systems, empirical regularities are brought to light and differences that originate from institutional characteristics are systematically assessed.

The aim of this article is twofold. First, by drawing on insights that have been developed in studies of the US Congress and testing their propositions in another political system such as the European Community (EC), ${ }^{1}$ this article shows that these theories are robust. They explain to a good extent the patterns of delegation across political systems. Secondly, instead of translating slavishly the arguments developed for the American context, this work gives careful consideration to how the institutional peculiarities of the Community require a reformulation of the existing propositions and the production of new hypotheses. It demonstrates how these institutional features, for example the decision rules of the legislature and the possibility of relying upon different administrators for policy implementation, reveal systematic differences in delegation and generate new insights for the comparative literature.

This work tackles the following questions. Who does what, in terms of policy

* School of Public Policy, University College London. I am indebted to the Journal reviewers and to Cliff Carrubba, Patrick Dunleavy, Jon Golub, Simon Hix, Dan Kelemen, Amie Kreppel, Mathias Koenig-Archibugi, Jeffrey Lewis, Fabrizio Gilardi, Mark Pollack, Berthold Rittberger, Cheryl Schonhardt-Bailey, George Tsebelis, Mark Thatcher, Eiko Thielemann and Diego Varela. I thank Eliana Colla and Alessandro Volcic for their valuable assistance and the participants at the London School of Economics and the London European Union group meetings, and at the panels in the meeting of the Societa Italiana di Scienza Politica, Naples, 2001; European Community Studies Association, Madison, 2001; American Political Science Association, San Francisco, 2001; and European Consortium for Political Research, Canterbury, 2001. Additional information and the dataset used for this study can be fount at http://www.ucl.ac.uk/spp/people/fabio_franchino.php.

${ }^{1}$ I use the term European Community because the empirical part of the article focuses only on the EC pillar of the Treaty on European Union. 
implementation, in the European Community? Why is a specific administrative actor in charge of execution? Why do administrators enjoy considerable authority in some policies while they are constrained in others? Understanding how these choices are made is a crucial exercise in the study of the Community because it sheds light on how the legislative and executive functions are structured both among Community-level institutions and between the supranational and national level of Community policy making. The study of executive politics contributes to the ongoing debate on the relative importance of national and supranational institutions in shaping the process of European integration. More importantly, it contributes to democratic theory as applied to the Community, as it focuses attention on the legitimacy of majority voting and on the role played by unelected supranational bureaucrats in policy implementation.

The study of delegation and agency discretion originates from theories of legislativeexecutive relations in American politics. From an initial emphasis on Congressional delegation to bureaucracy as a 'blame shifting' exercise, the field has developed various hypotheses on the legislators' decision to delegate policy authority, on the degree of agency discretion and on the choice of control mechanisms. ${ }^{2}$ The most systematic effort to explain delegation of powers is the work of Epstein and O'Halloran. These scholars have modelled the decision to delegate powers from the Congress to the US executive, distilled the factors that explain delegation and tested many hypotheses across a dataset of major bills. Two results are relevant for our purposes. First, Congress delegates less policy authority during times of divided government, that is when the executive and the legislative branches of government do not share the same policy preferences. Secondly, Congress delegates more discretionary authority to the executive in informationally intense, or complex, issue areas. $^{3}$

The literature is starting to move beyond the confined context of the American federal system. In an important study, Huber and Shipan have recently extended these insights to parliamentary systems and to systems of separation of powers at the US state level. ${ }^{4}$ They confirm the importance of policy conflict in determining the level of bureaucratic discretion

\footnotetext{
${ }^{2}$ A non-exhaustive list of relevant works includes Randall L. Calvert, Mathew D. McCubbins and Barry R. Weingast, 'A Theory of Political Control and Agency Discretion', American Journal of Political Science, 33 (1989), 588-611; Morris P. Fiorina, 'Legislator Uncertainty, Legislative Control, and the Delegation of Legislative Power', Journal of Law, Economics, and Organization, 2 (1986), 33-51; Mathew D. McCubbins and Terry Sullivan, eds, Congress: Structure and Policy (Cambridge: Cambridge University Press, 1987); D. Roderick Kiewiet and Mathew D. McCubbins, The Logic of Delegation: Congressional Parties and the Appropriations Process (Chicago: The University of Chicago Press, 1991); B. Dan Wood and Richard W. Waterman, 'The Dynamics of Political Control of the Bureaucracy', American Political Science Review, 85 (1991), 801-28.

${ }^{3}$ David Epstein and Sharyn O'Halloran, Delegating Powers: A Transaction Cost Politics Approach to Policy Making Under Separate Powers (Cambridge: Cambridge University Press, 1999), pp. 129-39, 197-219. Their model has been recently extended by Craig Volden, 'A Formal Model of the Politics of Delegation in a Separation of Powers System', American Journal of Political Science, 46 (2002), 111-33.

${ }^{4}$ They also note the paucity of theoretical development and systematic empirical testing in the comparative literature, John D. Huber and Charles R. Shipan, Deliberate Discretion? The Institutional Foundations of Bureaucratic Autonomy (Cambridge: Cambridge University Press, 2002), pp. 27-32. Notable exceptions related to bureaucratic delegation are John D. Huber, 'Delegation to Civil Servants in Parliamentary Democracies', European Journal of Political Research, 37 (2000), 397-413; John D. Huber and Arthur Lupia, 'Cabinet Instability and Delegation in Parliamentary Democracies', American Journal of Political Science, 45 (2001), 18-33; Terry M. Moe and Michael Caldwell, 'The Institutional Foundations of Democratic Government: A Comparison of Presidential and Parliamentary Systems', Journal of Institutional and Theoretical Economics, 150 (1994), 171-95; Mark Thatcher and Alec Stone Sweet, eds, 'The Politics of Delegation: Non-Majoritarian Institutions in Europe', Special Issue of West European Politics, 25 (2002).
} 
in both contexts and they introduce new variables. One that is important for our purposes is the bargaining environment within the legislature of separation of powers systems. Huber and Shipan assert that the executive is less likely to be constrained when it is harder to reach an agreement within the legislature. ${ }^{5}$ They find support for this proposition during times of divided government. The executive has more discretion when the two legislative chambers do not share policy preferences, namely when the legislature is divided too.

Finally, in his latest work Tsebelis has applied his theory of veto players also to the independence of bureaucracies. He argues that an increase in policy stability gives more discretion to bureaucrats. In a political system, high policy stability results from the presence of many legislative veto players with heterogeneous preferences. ${ }^{6}$

The delegation literature on the European Community has instead increased more substantially over the last few years, most likely because the Community has institutional features that are similar to a separation of powers system. ${ }^{7}$ In a seminal contribution, Pollack applies agency theory and reviews the control mechanisms used by member states to minimize losses that may originate from the delegation of powers to supranational institutions. ${ }^{8}$ Majone and Moravcsik contend that the delegation of policy-making functions to the Commission solves the problem of commitment by member states to specific policy objectives. ${ }^{9}$ Recently, Tallberg reviews the literature and reformulates the arguments of delegation to the Commission to shift blame, to improve the efficiency of decision making and to rely on its technical expertise. ${ }^{10}$

This article applies the main insights of Epstein and O'Halloran's theory of delegation to the European Community. The work is based on the premise that members of the Council of Ministers, like legislators in domestic contexts, set the boundaries of legislative and

${ }^{5}$ Huber and Shipan, Deliberate Discretion? pp. 103-6, 146-70.

${ }^{6}$ George Tsebelis, Veto Players: How Political Institutions Work (Princeton, N.J.: Princeton University Press, 2002), pp. 235-46. Also internal cohesion of collective veto players generates high policy stability (pp. 2-5).

${ }^{7}$ Alexander Ballmann, David Epstein and Sharyn O'Halloran, 'Delegation, Comitology, and the Separation of Powers in the European Union', International Organization, 56 (2002), 551-74; Francesca Bignami, 'The Administrative State in a Separation of Powers Constitution: Lessons for European Community Rulemaking from the United States', Jean Monnet Working Paper, $5 / 99$ (Cambridge, Mass.: Harvard Law School, 1999); Simon Hix, The Political System of the European Union (London: Macmillan, 1999), pp. 21-98; Koen Lenaerts, 'Some Reflections on the Separation of Powers in the European Community', Common Market Law Review, 28 (1991), $11-35$.

${ }^{8}$ Mark A. Pollack, 'Delegation, Agency, and Agenda Setting in the European Community', International Organization, 51 (1997), 99-134. See also Mark A. Pollack, 'The Commission as an Agent' in Neill Nugent, ed., At the Heart of the Union: Studies of the European Commission (London: Macmillan, 1997), pp. 109-28. Works on control mechanisms that explicitly refer to agency theory include Ballmann, Epstein and O'Halloran, 'Delegation, Comitology and the Separation of Powers in the European Union'; Fabio Franchino, 'Control of the Commission's Executive Functions: Uncertainty, Conflict and Decision Rules', European Union Politics, 1 (2000), 59-88; Jonas Tallberg, 'Delegation to Supranational Institutions: Why, How and with What Consequences?' West European Politics, 25 (2002), 23-46.

${ }^{9}$ Giandomenico Majone, Regulating Europe (London: Routledge, 1996); Andrew Moravcsik, The Choice for Europe: Social Purpose and State Power from Messina to Maastricht (Ithaca, N.Y.: Cornell University Press, 1998). See also Giandomenico Majone, 'Two Logics of Delegation: Agency and Fiduciary Relations in EU Governance', European Union Politics, 2 (2001), 103-22; Giandomenico Majone, 'The European Commission: the Limits of Centralisation, the Perils of Parliamentarisation', Governance, 15 (2002), 375-92.

${ }^{10}$ Tallberg, 'Delegation to Supranational Institutions', pp. 25-8. Delegation for technocratic reasons is the neofunctionalist argument of European integration studies; see, for instance, Leon N. Lindberg, The Political Dynamics of European Economic Integration (Stanford, Calif.: Stanford University Press, 1963); Ernst B. Haas 'Technocracy, Pluralism and the New Europe', in Stephen R. Graubard, A New Europe? (Boston, Mass.: Houghton Mifflin, 1964), pp. 65-85. 
administrative action, choose the actors upon whom they confer powers and the latitude of their authority. It argues that Community legislators care about the policy actions taken by the administrators and are willing to rely on their expertise in areas where they face uncertainty about the consequences of policy decisions. Since the actors in charge of implementing common policies are the European Commission and the member states, the article claims that their administrative features should guide the choice of delegation. However, legislators are also aware that administrators have their own preferences and could take actions that are inimical to their interests. A second proposition, then, is that decision rules are the best measures available for the risk of distributive losses confronting Community legislators.

The article develops and tests the following four predictions. The Council will delegate greater discretionary authority to the Commission in acts adopted under qualified majority voting, and in issue areas that require general and managerial skills at the supranational level; it will delegate greater executive discretion to the member states in acts adopted under unanimity, and in issue areas that require specialized and technical knowledge. These propositions are tested on a sample of 158 major EC legislative acts adopted since 1958 and corroborated. This exercise contributes to the EC literature on delegation in four ways. First, studies have focused so far mostly on the general institutional design of the Community, as resulting from the Treaty, rather than on its legislative output. In other words, they have dealt with 'constitutional' delegation, whereas I focus on executive delegation. Secondly, analyses have been limited to case studies of few policy areas. ${ }^{11}$ This work is systematic across all Community policies. Thirdly, current studies have focused almost exclusively on delegation to the Commission. They tend to disregard the fact that EC legislators can choose between the Commission and the national authorities for policy implementation and that, in the latter case, they set the degree of national executive discretion. ${ }^{12}$ This study shows that, if we consider these issues carefully, claims of delegation to the Commission for informational reasons must be reassessed. ${ }^{13}$ National

${ }^{11}$ A non-exhaustive list of case studies on the Commission that refer to agency and delegation theory includes Sophie Meunier, 'What Single Voice? European Institutions and EU-US Trade Negotiations', International Organization, 54 (2000), 103-35; Mark A. Pollack, 'The Engines of Integration? Supranational Autonomy and Influence in the European Union', in Wayne Sandholtz and Alec Stone Sweet, eds, European Integration and Supranational Governance (New York: Oxford University Press, 1998), pp. 217-49; Susanne K. Schmidt, 'Only an Agenda Setter? The European Commission's Power over the Council of Ministers', European Union Politics, 1 (2000), 37-61; Stephan Stetter, 'Regulating Migration: Authority Delegation in Justice and Home Affairs', Journal of European Public Policy, 7 (2000), 80-103; Mark Thatcher, 'The Commission and National Governments as Partners: EC Regulatory Expansion in Telecommunications', Journal of European Public Policy, 8 (2001), 558-84; Jonas Tallberg, 'The Anatomy of Autonomy: An Institutional Account of Variation in Supranational Influence', Journal of Common Market Studies, 38 (2000), 843-64.

${ }^{12}$ On this point, see also Fabio Franchino, 'Delegation and Constraints in the National Execution of the EC Policies: A Longitudinal and Qualitative Analysis', West European Politics, 24 (2001), 169-92; Jonas Tallberg, 'Supranational Influence in EU Enforcement: The ECJ and the Principle of State Liability', Journal of European Public Policy, 7 (2000), 104-21; Jonas Tallberg, 'Paths to Compliance: Enforcement, Management, and the European Union', International Organization, 56 (2002), 609-43. The selection of mechanisms that allow flexible national implementation is frequently considered in cases studies on Council negotiations, see, e.g., Rainer Eising, 'Policy Learning in Embedded Negotiations: Explaining EU Electricity Liberalization', International Organization, 56 (2002), 85-120; Beate Kohler-Koch and Rainer Eising, eds, The Transformation of Governance in the European Union (London: Routledge, 1999). For a recent model, see Antoaneta Dimitrova and Bernard Steunenberg, 'The Search for Convergence of National Policies in the European Union: An Impossible Quest?' European Union Politics, 1 (2000), 201-26.

13 Tallberg, 'Delegation to Supranational Institutions', pp. 26-7. 
administrators are the main providers of technical expertise in the Community, while the role of the Commission appears to be secondary, though not negligible. Moreover, by showing how national executive discretion varies across policies, I suggest that EC implementation studies should control for this factor before speculating on the degree of national policy convergence. Finally, the EC delegation literature has mostly ignored, and never tested empirically, how the legislative procedures of the Community, interacting with actors' preferences, determine specific delegation outcomes. ${ }^{14}$ This work shows that decision rules affect both the degree of discretionary policy authority enjoyed by each administrator and the choice between administrators.

This exercise also contributes to the comparative literature on delegation in three ways. First, these studies have rarely dealt with the choice between administrators ${ }^{15}$ and have never considered the impact of different decision rules within the same legislative body. Secondly, with regard to the work of Huber and Shipan, my results suggest that more conflict within the legislature may not lead to more discretion for the executive if the status quo is biased in favour of the legislators who do not share the executive's preferences. Finally, as far as veto players and bureaucratic autonomy are concerned, I contend that Tsebelis's argument is more likely to be valid for bureaucracies that have a significant level of formal or institutional independence. These points are discussed in greater detail in the final section of the article. The work is organized into three main sections. The first part outlines the insights of the theory of delegation propounded by Epstein and O'Halloran, and develops the hypotheses by applying them to the Community. The methodology used for the selection of major EC laws and the operationalization of the dependent and independent variables are explained in the second part. The last section shows how the empirical results corroborate the expectations. Finally, the conclusion discusses the results in the light of the comparative and EC literature on delegation and the normative debate on the democratic deficit of the Community.

\section{EPSTEIN AND O'HALLORAN'S THEORY OF DELEGATION}

Epstein and O'Halloran formulate two general propositions that are considered in this analysis. They take the lead from theories of congressional oversight and legislative organization and, for our purposes, the point of departure is the well-known contribution of McCubbins, Noll and Weingast. ${ }^{16}$ These scholars show that the problem confronting Congress when it delegates authority to an agency is bureaucratic drift, the ability of the agent to enact an outcome different from that preferred by its political principals. Agency

\footnotetext{
${ }^{14}$ A few case studies have tried to identify the conditions for Commission influence; see the review by Mark A. Pollack, 'Learning from the Americanists (Again): Theory and Method in the Study of Delegation', West European Politics, 25 (2002), 200-19, p. 212. Two formal works, based on the veto player argument, have produced propositions on the Commission's discretion that relate indirectly to this work. They will be discussed in detail in the conclusion, see Jenna Bednar, John Ferejohn and Geoffrey Garrett, 'The Politics of European Federalism', International Review of Law and Economics, 16 (1996), 279-94; George Tsebelis and Geoffrey Garrett, 'The Institutional Foundations of Intergovernmentalism and Supranationalism in the European Union', International Organization, 55 (2001), 357-90.

${ }^{15}$ Epstein and O'Halloran have analysed delegation to independent agencies in Delegating Powers, pp. 154-61; see also Volden, 'A Formal Model of the Politics of Delegation in a Separation of Powers System'.

${ }^{16}$ Mathew D. McCubbins, Roger G. Noll and Barry R. Weingast, 'Structure and Process, Politics and Policy: Administrative Arrangements and the Political Control of Agencies', Virginia Law Review, 75 (1989), 431-82; Mathew D. McCubbins, Roger G. Noll and Barry R. Weingast, 'Administrative Procedures as Instruments of Political Control', Journal of Law, Economics, and Organization, 3 (1987), 243-77.
} 
discretion hence encompasses all those actions that no political coalition can overturn. Epstein and O'Halloran, however, argue that legislators use a much more direct method to constrain the agent. Instead of relying on the ex-post sanction of new legislation or on other forms of ongoing control mechanisms, they explicitly limit, in the enacted legislation, the ability of bureaucrats to move outcomes away from the status quo. The important innovation of Epstein and O'Halloran is that they make agency discretion the choice variable for legislators. This discretion, as delineated in the statutes, becomes the core dependent variable in their analysis. ${ }^{17}$

One of its main determinants is the divergence between the preferences of the legislature and those of the executive. If preferences are far apart, bureaucrats are more likely to drift. The legislature, anticipating this, will confer less discretion upon the agent. Hence, we should expect less discretionary authority being delegated to the executive when agency drift is more likely. ${ }^{18}$

The second strand of literature on which Epstein and O'Halloran rely is the informational theory of agency and of legislative committees. ${ }^{19}$ Legislators delegate powers because they want to reduce workload and take advantage of expertise. In issue areas where the link between policy and outcome is more uncertain, legislators face greater complexity and will have to gather more information to produce detailed legislation. But this activity has an opportunity cost, in terms of the forgone constituency service, for instance. Legislators will then have a greater incentive to rely on bureaucratic expertise. In sum, more policy authority should be delegated to the executive in informationally intense issue areas. ${ }^{20}$

\section{THE THEORY APPLIED TO THE EUROPEAN COMMUNITY}

Community legislators face challenges that do not differ from those confronting legislators in other political systems. When they adopt legislation, they care about the actions taken by the administrators, so they have to make sure that policies are implemented in ways that are not at odds with their own preferences. Equally, legislators want to optimize the use of their time and resources. Hence, when they are more uncertain about the outcomes of their policy actions, they are more likely to rely on bureaucratic expertise.

A theory of delegation applied to the Community needs to identify, first, the institutions that decide how much power to delegate in the implementation of common policies. Secondly, it must incorporate this decision into the legislative process of the Community in order to specify exactly how agency drift and information intensity affect delegation within this political system. Thirdly, it must identify the main actors upon which these powers are delegated because their characteristics are likely to explain choices of delegation too.

\section{The Institutions Delegating Powers}

For an important set of EC secondary legislation, the decision to delegate policy authority nowadays rests with the Council of Ministers and the European Parliament. The legislative

${ }^{17}$ Epstein and O'Halloran, Delegating Powers, pp. 26, 74-5.

${ }^{18}$ Epstein and O'Halloran, Delegating Powers, pp. 75, 79.

${ }^{19}$ Keith Krehbiel, Information and Legislative Organization (Ann Arbor: University of Michigan, 1991); Mathew D. McCubbins, 'The Legislative Design of Regulatory Structure', American Journal of Political Science, 29 (1985), 721-48.

${ }^{20}$ Epstein and O'Halloran, Delegating Powers, pp. 75, 85. 
power of the parliament has, however, increased only recently and this is reflected in the sample of acts used for this article. The parliament has not been involved in fourteen out of the 158 laws and it has issued merely a non-binding opinion in 131 acts. Only thirteen laws have been adopted in co-operation with it, a legislative procedure that grants the parliament a moderate influence. Consequently, I shall disregard this institution in this article. It should be subject to future research that focuses on a more recent time horizon.

Historically, but still in the present institutional context, the Council has been then the main Community institution taking delegating decisions. However, the Council is not a classic legislature. Its members enjoy far more resources than do traditional legislators and, as we shall see, they have the option of delegating powers to their national administrations. Nevertheless, I will argue that ministers face trade-offs that do not differ from those of traditional legislators and they have to take, at the margin, similar decisions.

\section{The EC Legislative Process}

For our purposes, the EC legislative process involves the European Commission and the Council only. The Commission enjoys the sole right to initiate legislation on which the Council then deliberates subject to one of two different decision rules - unanimity and qualified majority voting. ${ }^{21}$ I will argue that the first feature of this process, the Commission's right of initiative, does not determine per se the executive discretion enjoyed by Community administrators in policy implementation. The second feature, the decision rules, is instead at the core of the explanation of how the risk of agency drift affects delegation in the Community. ${ }^{22}$

\section{Delegation to the European Commission}

The choice to delegate is frequently, but not always, exercised by the Council. There is no delegation of powers, hence no executive discretion, in 6 per cent of the acts sampled for this article (five directives and five regulations). No powers have been delegated by the first regulation establishing the common customs tariff (no. 950/68) or by the first directives abolishing restrictions on freedom of establishment and to provide services (for example, nos. 63/340 and 64/225). If delegation takes place, the Council can choose between at least two agents. Their features constitute part of the explanatory framework proposed here. In this section, I shall focus on delegation to the Commission, which occurs in less than half of the cases in the sample (seventy-one acts). Delegation to member states is discussed in the next section.

In formulating the hypotheses, I will also refer to propositions of a formal model that applies the main intuitions of Epstein and O'Halloran to the Community and that takes into

\footnotetext{
${ }^{21}$ This procedure is called consultation when the European Parliament issues a non-binding opinion that does not affect outcomes. Since the European Parliament can be consulted when either unanimity or majority voting is used, I only refer to the decision rule of the Council. Finally, for completeness, the Council can amend the Commission's proposal by unanimity when majority voting applies.

22 This argument is coherent with Moravcsik's view that qualified majority voting is a means to commit governments to specific policy objectives: Moravcsik, The Choice for Europe, pp. 73-7, 485-9. My propositions show how decision rules operate as a technology of commitment. Credibility is achieved in areas under qualified majority voting by restricting national executive action and by granting greater discretion to a supranational bureaucracy. For a formal proof, see Fabio Franchino, 'A Formal Model of Delegation in the European Union' (paper read at the Annual Meeting of the American Political Science Association, Boston, Mass., 2002).
} 
account the peculiarities of the EC legislative process. ${ }^{23}$ The model considers delegation of executive powers to the Commission only. It builds on the work of Crombez ${ }^{24}$ and starts with the Commission proposing a degree of discretion that has to be approved by the Council subject to the relevant decision rule. The Commission then implements the policy within set discretionary limits, after the state of nature is revealed.

Similar to Epstein and O'Halloran, the choice variable for Community legislators is the degree of executive discretion enjoyed by the Commission in the implementation of common policies. The Council can delimit this discretion directly through law and rely on the European Court of Justice to overturn its actions. ${ }^{25}$ Few examples can illustrate this option available to the Council. Directive $72 / 160$ specifies that the Commission can finance only 25 per cent of the cost of a project on the cessation of farming. Many regulations on competition (for example, nos. 17/62 and 4056/86) set upper limits on the penalties that the Commission can impose on companies abusing dominant positions. Finally, in Directive 89/646 the Commission needs an authorization from the Council to start negotiation with third countries on market access for credit institutions.

Unsurprisingly, the Commission prefers more to less executive discretion and will use its power of initiation to maximize its policy authority. ${ }^{26}$ However, since this prerogative to propose legislation is a constant feature of the EC decision-making process, it cannot explain variation in the discretion of the Commission (and, for that matter, of national administrations) across Community laws. It only operates in the development of hypotheses in conjunction with other explanatory components. Instead, three independent factors vary across issues and they form the basis of two testable propositions about the Commission's discretion. ${ }^{27}$ These are decision rules, configuration of preferences and information intensity. The first two are related to agency drift.

Decision rules: For most preference configurations, greater executive discretion should be conferred upon the Commission in an act adopted under qualified majority voting. The rationale behind this prediction is simple. ${ }^{28}$ Rules determine the degree of discretion to

${ }^{23}$ Fabio Franchino, 'The Commission's Executive Discretion, Information and Comitology', Journal of Theoretical Politics, 12 (2000), 155-81.

${ }^{24}$ Christophe Crombez, 'Legislative Procedures in the European Community', British Journal of Political Science, 26 (1996), 199-228.

${ }^{25}$ The Court too makes strategic calculations in its decision making and its pro-integration preferences may increase the Commission's leeway in implementation. However, the Court cannot disregard, without losing credibility, its Treaty role of upholding EC law when the Commission's acts are ultra vires, especially where the Council's mandate is clear, see, e.g., Geoffrey Garrett, R. Daniel Kelemen and Heiner Schulz, 'The European Court of Justice, National Governments, and Legal Integration in the European Union', International Organization, 52 (1998), 149-76; Karen J. Alter, "Who Are the "Masters of the Treaty"? European Governments and the European Court of Justice', International Organization, 52 (1998), 121-47. Further, I am aware of only a handful of cases of successful Commission-Court co-operation, see, e.g., Simon Bulmer, 'Institutions and Policy Change in the European Communities: The Case of Merger Control', Public Administration, 72 (1994), 431-2; Wayne Sandholtz, 'The Emergence of a Supranational Telecommunication Regime', in Wayne Sandholtz and Alec Stone Sweet, eds, European Integration and Supranational Governance (New York: Oxford University Press, 1998), 153-60; Schmidt, 'Only an Agenda Setter?'

${ }^{26}$ Franchino, 'The Commission's Executive Discretion, Information and Comitology', p. 161.

${ }^{27}$ Franchino, 'The Commission's Executive Discretion, Information and Comitology', pp. 164-6.

${ }^{28}$ This is proposition 1.1 in Franchino, 'The Commission's Executive Discretion, Information and Comitology', p. 164. However, three qualifications are needed. First, the proposition refers to the assent procedure rather than to unanimity. This procedure requires unanimity in the Council and the approval of the European Parliament (EP) under a closed rule. Nevertheless, the hypothesis is unaffected because, under assent, the EP can only reduce the 
grant upon the agents and, as such, reflect the conflict between legislators and agents. Delegation of powers to the Commission under unanimity is driven by the member state that fears agency drift the most. If the decision rule is instead qualified majority voting, we should expect more delegation given the likelihood of a greater affinity between the preferences of the Commission and those of the pivotal government. Moreover, since the Commission will try to maximize its room of manœuvre, it will propose the highest degree of discretion that satisfies the pivotal government under qualified majority voting. Given the likelihood of heterogeneous preferences in the Council, this discretion will be larger than the one conferred under unanimity. This outcome is most probably predicted by the governments. Hence, in Treaty negotiations, they are more likely to move to majority voting those policy areas that need greater executive involvement of the Commission.

Configuration of preferences: For a given decision rule, convergence between the preferences of the Commission and of the pivotal member state should increase the discretion conferred upon the Commission because the risk of agency drift is reduced. ${ }^{29}$ The distribution of preferences then mediates and may negate the institutional determinants of EC decision making. It is plausible to foresee the case whereby the Council confers, under unanimity, considerable discretion upon a moderate Commission, while it restrains, under qualified majority voting, a Commission with extreme preferences. However, I have not included in the empirical analysis a variable measuring actors' preferences for two reasons. First, to my knowledge, there are no comparable cross-policy data on the preferences of the governments and of the Commission. This is mostly because of the secrecy of the proceedings inside the Council. Attempts to operationalize preferences for a narrow set of issue areas have yielded interesting results, but extensions to larger datasets have been disappointing. ${ }^{30}$

Secondly, one could argue that decision rules in the Community are endogenous with respect to the underlying policy preferences of member states. ${ }^{31}$ Unanimity is maintained

(F'note continued)

discretion that would have been otherwise conferred by a unanimous Council. Moreover, no acts in the sample are adopted using this procedure. Secondly, the hypothesis is unaffected also for the thirteen acts adopted in co-operation with the EP. This procedure gives the EP the power to propose amendments that, if accepted by the Commission, the Council adopts by qualified majority voting or rejects unanimously. The EP can reduce the discretion that would have been otherwise conferred by the Council under qualified majority voting. But, it will not be smaller than the discretion conferred by a unanimous Council. Thirdly, because of the Commission's power to propose, proposition 1.1 limits the impact of the decision rules on discretion to cases where the status quo discretion is null or small. This applies to more than 88 per cent of the acts in the sample ( 140 laws) because this legislation either does not amend previous acts or amends acts where no powers were delegated to the Commission. The amendments in two of the remaining cases are of minor importance (Directive 63/21 and Regulation 355/77). They amend only one paragraph, with no implication for the Commission, they legislate on new issues and they can be treated as cases where the status quo discretion is null. In sixteen other cases, the act repeals previous legislation entirely, thus powers are delegated ex novo. They also can be treated as acts with no status quo discretion. This consideration applies also to proposition 2.1.

${ }^{29}$ This is proposition 2.1 in Franchino, 'The Commission's Executive Discretion, Information and Comitology', p. 165.

${ }^{30}$ See Bruce Bueno de Mesquita and Frans N. Stokman, eds, European Community Decision Making: Models, Applications, and Comparisons (New Haven, Conn.: Yale University Press, 1994); Gerald Schneider and Stefanie Bailer, 'The Winners and Losers of European Integration: An Empirical Evaluation of Competing Bargaining Models' (paper read at the Annual Meeting of the American Political Science Association, San Francisco, 2001). For an unsuccessful attempt, see Fabio Franchino, 'Statutory Discretion and Procedural Control of the European Commission's Executive Functions', Journal of Legislative Studies, 6 (2000), 28-50.

${ }^{31}$ See Franchino, 'Control of the Commission's Executive Functions', pp. 76-7; Jonathan Golub, 'In the Shadow of the Vote? Decision Making in the European Community', International Organization, 53 (1999), 733-64, pp. 752; Moravcsik, The Choice for Europe, pp. 474-5, 486-7. 
in controversial policy areas where governments want limited EC-level legislation and where they certainly do not want the Commission involved in implementation. For instance, unanimity in social security legislation (Article 42 EC) has survived three Treaty amendments and the Commission still plays no role in implementation, even though the parliament now co-decides with the Council. This area is one of the very few cases where the Council has decided to delegate powers to an EC level institution outside the influence of the Commission (i.e. the Administrative Commission on Social Security for Migrant Workers, see regulation 3/58). Similarly, unanimity remains in Article 18 EC on residence rights. This area covers delicate civil rights and the Commission has no executive powers (see, for example, Directives 90/364-5). Finally, taxation, another highly contentious area, firmly remains under unanimous voting (Article $93 \mathrm{EC}$ ). The Commission has no role in the implementation of the main acts on indirect taxation. It is only in charge of defining some rules of administrative co-operation among ministries (Regulation 218/92). Instead, a shift from unanimity to qualified majority voting signals convergence of policy preferences, greater acceptance of EC legislative output and greater willingness to delegate powers to the Commission. The model of Carrubba and Volden on the choice of voting rules by the Council shows a degree of correlation between preference convergence and moves to majority voting. ${ }^{32}$ The adoption of the 1986 Single European Act (SEA) is a paradigmatic example. Moravcsik argues how rising economic interdependence and perceived domestic policy failure led to a shift of the French policy from a 'Socialist' towards a 'Conservative' Europe. ${ }^{33}$ As a result, the French position on the extension of qualified majority voting to new areas shifted from opposition to limited support. As for the policy output, Article 16.4 SEA introduced majority voting in the area of capital movements and this change led to extensive liberalization (Directive 88/361). The same procedural change (Article 16.5 SEA) led to the extension of competition rules to air transport (Regulations 3975-6/87). Finally, the introduction of Article 95 EC allowing the approximation of laws under qualified majority voting (Article 18 SEA) has unlocked many proposals in this field, from toy safety to trade marks and legal protection of computer programs (Directives 88/378, 89/104 and 91/250 respectively).

I will not argue too strenuously in support of the endogeneity of voting rules. One should not get the impression that governments enjoy harmonious relations in areas under majority voting, such as agriculture and commercial policy, or that there was insurmountable conflict across member states when the first environmental directives were unanimously adopted in the 1970s. Further, Moravcsik argues that support for qualified majority voting derives from the need to commit governments credibly to the substantive objectives of European policies. Logrolling during negotiations may also explain its extension to new issues ${ }^{34}$ However, since we lack reliable data to include the preference variable, the fact that we could expect a certain degree of collinearity with voting rules reinforces the case for its exclusion.

Information intensity: Ministers undoubtedly enjoy a wide array of instruments and resources as the heads of their national departments and of their national representations

\footnotetext{
${ }^{32}$ Clifford J. Carrubba and Craig Volden, 'Explaining Institutional Change in the European Union: What Determines the Voting Rule in the Council of Ministers?' European Union Politics, 2 (2001), 5-30.

${ }^{33}$ Moravcsik, The Choice for Europe, pp. 332-43.

${ }^{34}$ These qualifications do not change the basic thrust of the argument because shifts in substantive preferences predate the choice of commitment technologies and issue-linkages seldom occur; see Moravcsik, The Choice for Europe, pp. 473-89.
} 
within the Council administration. ${ }^{35}$ Such resources, certainly not available to national legislators, can explain the generally high level of specificity of Community legislation, compared to other political systems, that many scholars have observed. However, resources cannot explain variation across laws since their amounts are normally fixed.

Moreover, the abundance of resources allows ministers to undertake a large number of diverse political activities, but this does not imply that any specific one, such as legislating within the Council, has no opportunity cost. Ministers are essentially motivated by the need to maximize their chances of re-election and the chances of electoral re-endorsement of their government. ${ }^{36}$ Time and resources spent in specifying to the minutest detail the implementation of a European policy are time and resources diverted from constituency, government and other, even EC related, services.

At the margin, ministers face, within the Council, a trade-off that is similar to those of traditional legislators. They have to choose whether they want to (a) specify further the provisions of a European law and/or take decisions within the Council or (b) delegate these activities to an agent. Paraphrasing Epstein and O'Halloran, ${ }^{37}$ ministers begin to delegate authority at the point where the marginal returns to favoured constituents from enacting a specific European policy equal the marginal returns from casework or from other services to their government.

Ministers have lower incentives to produce detailed laws in informationally intense issue areas where the opportunity cost of legislating, in terms of forgone constituency and government service, is greater. We should hence expect more delegation of policy authority. ${ }^{38}$ However, the Council can rely either on the Commission or the member states to take advantage of reduced workload and agency expertise. The difference between these two agents is likely to guide the delegation decision of the Council. In comparison with national ministries, the Commission is a small supranational bureaucracy made up predominantly of general administrators, lawyers, economists and other social scientists. The main recruitment mechanism, a competitive examination (the concours), is also normally biased in favour of generalist, legal or economic knowledge. Studies on the background and expertise of the Commission's personnel and the degree of interdepartmental mobility do not suggest a marked professional specialization. ${ }^{39}$

These administrative features are the indirect product of the Council's decisions over time. Complexity in some areas may result from legislation that is designed to limit national authority, so a supranational bureaucracy is better suited to relieving the Council of its workload. It is plausible that one of the functions of the Commission's personnel is simply to make the Council's decision making more efficient since this delegation saves directly ministerial time and resources at the supranational level. ${ }^{40}$ In sum, we should expect the

\footnotetext{
35 The Committee of Permanent Representatives is the main organ of the Council administration. It is mostly staffed by senior civil servants from national ministries. They are therefore under the control of the relevant minister. A small Council Secretariat performs administrative duties for the whole Council. See Fiona Hayes-Renshaw and Helen Wallace, The Council of Ministers (London: Macmillan, 1997), pp. 70-133.

${ }^{36}$ Simon Hix, The Political System of the European Union (London: Macmillan, 1999), p. 63.

${ }^{37}$ Epstein and O'Halloran, Delegating Powers, p. 30.

${ }^{38}$ See proposition 2.1 in Franchino, 'The Commission's Executive Discretion, Information and Comitology', p. 165.

${ }^{39}$ David Spence 'Staff and Personnel Policy in the Commission' in Geoffrey Edwards and David Spence, eds, The European Commission (Harlow, Essex: Longman, 1994), pp. 62-94, at pp. 65-8; Anne Stevens and Handley Stevens, Brussels Bureaucrats? (New York: Palgrave, 2001), pp. 122-5; Neill Nugent, The European Commission (New York: Palgrave, 2001), pp. 162-85.

${ }^{40}$ Tallberg, 'Delegation to Supranational Institutions', p. 27. Admittedly, delegation to the Commission might still use up some ministerial resources as the permanent representatives might be involved with the Commission in implementation through the so-called 'comitology' procedures. Delegation, however, saves Council work for the individual minister.
} 
Council to delegate more policy authority to the Commission in issue areas that require general and managerial skills at the supranational level.

\section{Delegation to Member States}

The delegation of policy authority to member states, their competent authorities and institutions is far more common. Member states are asked to take implementation measures in 138 acts, more than 87 per cent of the sample. Undoubtedly, from the point of view of each individual member of the Council, this is not delegation as the powers are normally conferred upon their own ministries. However, this is delegation of powers from the point of view of the Council as a collective body. It is also delegation if we see it from the standpoint of, say, the French minister expecting the Portuguese Ministério do Ambiente to implement an environmental directive. ${ }^{41}$ At the most general level, the Council asks the member states to take various forms of action. For instance, member states must take the necessary measures to ensure that production models of motor vehicles conform to the approved types (Directive 70/156). States must ensure that the training of individuals responsible for accounting audits is carried out under persons providing adequate guarantees (Directive 84/253). Regulation 11/60 asks member states to lay down penalties for companies using discriminatory transport rates.

Sometimes the Council empowers individual ministries, frequently referred to as the 'national competent authorities'. For instance, national education ministries must lay down the detailed rules governing the adaptation period and aptitude tests that are at the basis of the general system for the mutual recognition of diplomas (Directives 89/48 and 92/51). Regulation 218/92 grants national treasuries the power to obtain information on indirect taxation from their counterparts.

The Council can be even more specific as to the national actor upon which implementing powers are conferred. In regulations on social security for migrant workers (such as Regulation 574/72), the Council requires the national competent institutions, for instance the Belgian Institut national d'assurance maladie-invalidité or the German Allgemeine Ortskrankenkasse, to decide on the granting of sickness benefits when persons reside outside their competent member state. In directives on insurance (such as Directives 73/279 and 79/267), national supervisory authorities of a company's head office are given the powers to verify its state of solvency.

One could presume that ministers would always prefer more to less discretion when their own administrations execute an EC law. This need not be the case. My contention is that one of the key reasons for adopting such a law in first place is that members of the Council care about policy actions taken by all member states. Ministers are then faced with the risk that some national authorities may not implement these policies faithfully, thus undermining the value of Community legislation. I call this the risk of national agency drift, as the member states are the executive agents of the Community.

As with the Commission, three factors should independently affect the delegation of executive powers to member states: decision rules, configuration of preferences and information intensity. For the problems that we mentioned, we will have to disregard the preference variable. Nonetheless, it will partially inform the hypothesis based on decision rules, which gauge the risk of national agency drift.

41 Franchino, 'Delegation and Constraints in the National Execution of the EC Policies'; Tallberg, 'Supranational Influence in EU Enforcement'; Tallberg, 'Paths to Compliance'. 
Decision rules: We should expect the Council to delegate greater executive discretion to national authorities if an act is adopted under the unanimity rule. Three reasons can be produced in support of this proposition. First, as argued, voting rules could be endogenous on the underlying distribution of member state preferences. Unanimity signals the willingness of governments to minimize interference from Brussels and to maximize national room of manœuvre in the relevant policy area. Secondly, I have referred to the likelihood that excessive national discretion in the implementation of Community policies could undermine the value of the relevant legislation because some national authorities could drift and easily revert to their pre-existing or preferred policies. A supranational institution such as the Commission may dislike this outcome and use its power of initiative to restrain national executive action. This can be more easily pursued when the Commission needs to secure the support for its proposal only from a qualified majority of governments, rather than from all of them. This is reinforced by the fact that governments, anticipating this outcome, are more likely to move to majority voting issue areas with a greater risk of national agency drift. Finally, the reversion points for most of the acts included in the sample are the existing national policies (see fn. 28). This implies complete discretion at the national level. The legislative outcome under unanimity is likely to reflect the preferences of the member state that wants to preserve the existing national prerogatives the most.

Information intensity: The Council can also rely on the member states for the execution of informationally intense policies. Delegation to national authorities saves Council work for each minister, but it burdens their national administrations. However, this does not change behaviour at the margin, as national delegation will take place at the point where the marginal returns to constituents from work in the Council equal the marginal returns from work in the home state.

The delegation to national authorities is guided by the fact that they have far greater resources and technical expertise than the Commission. The Council can rely on national engineers to check the conformity of motor vehicles to the approved production types, on national biologists to ensure the safe disposal of industrial waste and on national accountants to oversee the listing of securities on the stock exchange. National bureaucracies also hold important politically relevant information that the Council may rely upon. They are likely to have a better idea of how the possibility of claiming social security benefits outside of the competent member state can burden the system. They can better assess how the general system on the mutual recognition of diplomas may affect the movement of professionals and the domestic provision of professional services.

The situation resembles that facing Congress and the US administration. It is the intrinsic complexity of the policy (i.e. not resulting from Council's decisions) that should guide delegation in this case. National expertise is more valuable to the Council than supranational generalist skills. Therefore, we should expect greater delegation of executive powers to the member states in issue areas that require specialized and technical knowledge.

THE SELECTION OF MAJOR EC LAWS AND THE DATASET

The procedure for selecting major EC laws should be systematic and minimize bias. It should also employ a neutral method to separate significant from trivial legislation. In compiling a list of important post-war US legislation, Mayhew wanted to capture both 
retrospective and contemporary judgements on law production. ${ }^{42}$ He used references in scholarly books and year-end roundups of both the New York Times and Washington Post. To my knowledge, there are no lists available of major EC laws, yearly commentaries or publications that are selective enough and can be used systematically from 1958 onwards. I have chosen an approach that mimics Mayhew's methodology and tries to avoid serious selection biases.

The procedure consists of three stages. ${ }^{43}$ First, I have collected all the books on EC law published between 1958 and 1999 and available from the British Library of Political and Economic Science of the London School of Economics and Political Science. This exercise has produced a list of fifty-eight books. It includes three Italian texts, two German, French and Dutch publications, respectively, one Irish text and one official EC publication. The remaining are British books. Three books were published in the 1960s, five in the 1970s, sixteen in the 1980s and the remainder in the 1990s. There are eleven handbooks with abstracts on EC law, four textbooks on EC national law, two books on substantive EC law and the remaining are textbooks on EC law only.

The second stage is the creation of a database listing (1) the Council directives and regulations cited by these books and (2) the number of books citing each law. For this exercise, I have considered only the book sections on EC policies, on the budget and on general secondary legislation. The database includes 2,835 directives and regulations that can be sorted by number of citations. For instance, only seven acts have been cited by forty or more books while forty-three acts have been cited by at least twenty books.

The last stage is the selection of the major laws. The initial dataset for this article included the 169 directives and regulations that have at least ten citations. However, I had to eliminate eleven acts. Five regulations and four directives have been removed because law books normally refer to legislation in force at the time of publication, so minor amendments of major laws are dragged into the sample by the significance of the parent legislation. Regulation 2001/83 on social security has been removed because it consolidates, with minor amendments, two major laws adopted only two years earlier. Finally, Directive 90/366 on the right of residence for students has been annulled by the Court of Justice for procedural reasons. The Council adopted the correct version three years later (Directive 93/96). Only the second directive has been included in the sample. Regulation 2001/83 and Directive 90/366 have been frequently cited by law books for reasons of completeness, but they have been removed because they repeat, in almost identical terms, other major laws adopted in the same period. This brings the final number of acts in the dataset down to 158. It implies an analysis of more than 7,000 major legal provisions.

Books on EC law tend to refer to those acts that the academic community studying the EC considers of major legal and political significance. Hence the process so far captures retrospective judgements on the legislative output of the Community. In order to include contemporary judgements also, I have used the General Report on the Activities of the European Communities, published annually. All the laws in the dataset have been mentioned by at least a paragraph of the sections of the Report on the EC activities.

\footnotetext{
${ }^{42}$ David R. Mayhew, Divided We Govern: Party Control, Lawmaking, and Investigations, 1946-1990 (New Haven, Conn.: Yale University Press, 1991).

${ }^{43}$ Additional information on the procedure can be found at the website address listed in the acknowledgement.
} 
This section explains the operationalization of executive discretion and of the independent variables.

Executive discretion: I have followed Epstein and O'Halloran in the development of a measure of executive discretion. ${ }^{44}$ Here, I outline its main components. ${ }^{45}$ The dependent variable is the discretion as it results from reading the statutes. The procedure consists of two steps. First, I have identified the number of major provisions for each act in the sample and each provision has been coded as to whether or not it delegates executive powers. Delegation is the granting of substantive policy discretion by the Council to the Commission, member states or national institutions. The first component of the discretion variable is the delegation ratio, that is the proportion of major provisions in a legislative act that delegate policy authority. Secondly, I have identified twelve possible categories of procedural constraints that the Council can impose on the Commission or on the member states while they exercise their delegated powers. I have then recorded, for each law, which constraint appears at least once and developed the second component of the discretion variable. This is the constraint ratio, that is the number of constraints observed in a given law divided by the number of possible constraints. This ratio is then weighted by the delegation ratio and the resulting value is subtracted from the delegation ratio to give the following measure of executive discretion:

$$
d_{i}=D_{i} / M-\left[\left(C_{i} / T C\right) \times\left(D_{i} / M\right)\right]
$$

for $i=c, g$, where $d_{i}$ is the executive discretion enjoyed by either the Commission $\left(d_{c}\right)$ or the member states $\left(d_{g}\right), M$ is the number of major provisions in an act, $D_{i}$ is the number of provisions delegating authority either to the Commission $\left(D_{c}\right)$ or to the member states $\left(D_{g}\right), C_{i}$ is the number of constraints imposed either on the Commission $\left(C_{c}\right)$ or on the national authorities $\left(C_{g}\right)$ and $T C$ is the total number of possible constraints (twelve). $D_{i} / M$ is the delegation ratio and $C_{i} / T C$ is the constraint ratio.

In sum, executive discretion is measured by the share of major provisions delegating powers in an act, weighted by the constraints imposed on executive action. For instance, seven out of forty-nine provisions delegate executive powers to the Commission in Regulation 2641/84 on the new commercial policy instrument (a delegation ratio of 14 per cent). The Commission has the authority to open up and terminate an examination procedure, to carry out an investigation and to initiate a consultation or a dispute settlement procedure with third countries in response to illicit practices. However, the Commission is constrained by criteria defining injury and threat of injury, by the obligation to consult, at various stages, an advisory committee, to hold public hearings with interested parties and to present a report on its investigation. Further, the Council can revise a Commission's decision by qualified majority voting if, within a few days, it is referred by a member state to the Council. Finally, cases covered by existing commercial policy rules are exempted from the scope of the regulation. With six constraints and a constraint ratio of 43 per cent, the executive discretion of the Commission in this act is 8 per cent.

In Directive 79/279 co-ordinating the conditions for the admission of securities to the stock exchange, eighteen out of forty-five provisions delegate powers to member states and

\footnotetext{
${ }^{44}$ Epstein and O’Halloran, Delegating Powers, pp. 90-112.

${ }^{45}$ A more detailed explanation is to be found in the Appendix to the website version of this article.
} 
their competent authorities. At the general level, a member state may exempt some securities from the provisions of the directive and authorize derogations. More specifically, national competent authorities may refuse the listing of a security or decide the suspension of listing. Constraints are few. There are minimum requirements for the admission of securities and conditions for the derogations. The issuer had to be consulted prior to the diffusion of some information and member states must ensure the right to apply to the courts if a competent authority refuses the admission of a security to the stock exchange. The executive discretion of member states is considerable. It is almost 32 per cent. The Commission is only in charge of adjusting the minimum amount of market capitalization for the listing of securities. Further, a committee of national representatives oversees this Commission's power following an administrative procedure called regulatory committee procedure. Hence, the Commission's executive discretion is very small, only 2 per cent.

Decision rules: I use for the regression analysis a dichotomous variable taking the value of 1 for qualified majority voting and 0 for unanimity.

Information intensity: I employ first a simple descriptive method to assess the impact of informational intensity on executive discretion. Following the procedure used by Epstein and O'Halloran, ${ }^{46}$ I have classified the major EC laws into categories and compared the average levels of discretion across them. The bases of the EC Treaty provide the first level of classification but issue areas such as approximation of laws, economic policy, social provisions and freedom of establishment and to provide services are too broad. Hence, I have adopted a more fine-grained classification and separated acts that are substantively different and show different levels of discretion. The general aim is to give the best possible visual representation of the pattern of delegation.

For the direct test, the idea is to develop reasonable proxies for issue complexity that can be used across policies and time. Krehbiel uses the number of laws cited in a given act but, with more than 80 per cent of the major EC laws not amending previous legislation, this measure cannot be used. ${ }^{47}$ Elsewhere, I have employed the length of legislation as a proxy of complexity. ${ }^{48}$ This measure is subject to the criticism that legislators facing high informational costs actually have lower incentives to write detailed provisions and may be more concise.

Although no measure is likely to be completely satisfactory, I suggest three proxies. One is related to delegation to the Commission, the remaining two are associated with delegation to national authorities.

The first proxy is the number of major provisions in an act that call for 'detailed rules' to be adopted (modalités d'application in the French legislation). It is not unusual for the detailed implementation of the whole act or of a specific article to be subject to further proceedings. This is the case in about 40 per cent of the acts in the sample. I suggest that the Council will make more frequent use of these provisions in more complex issue areas. But, more importantly, this postponement is a sign of the need of the Council to reduce its workload, especially where policy complexity is its own product. Therefore, my

\footnotetext{
${ }^{46}$ Epstein and O'Halloran, Delegating Powers, pp. 197-200.

${ }^{47}$ Krehbiel, Information and Legislative Organization.

${ }^{48}$ Franchino, 'Control of the Commission's Executive Functions'; Franchino, 'Statutory Discretion and Procedural Control of the Commission's Executive Functions'.
} 
contention is that the Council is likely to make greater use of the generalist and supranational personnel of the Commission in this case. In sum, the number of major provisions in an act calling for 'detailed rules' to be adopted should be positively correlated with the Commission's executive discretion.

Epstein and O'Halloran use the number of committee hearings to gauge the information intensity of an issue area. ${ }^{49}$ This is because hearings are used as information gathering tools for legislators in the US Congress. Similarly, I relate the other two measures of complexity to the role of the Commission as initiator of EC legislation and to the technical committees involved in the drafting of legislation. The Commission is frequently prompted by member states, the European Parliament or interest groups to make some proposals. Other times it acts on its own. In the most complex areas, it gathers the relevant information on the issue and drafts a report, normally called general or action programme, containing a list of initiatives that could be taken. These reports are both a sign of information gathering and an instrument to induce the relevant political actors to signal support or voice opposition to the measures. The General Programmes for the Abolition of Restrictions on Freedom to Provide Services and of Establishment, drafted a few years after the Treaty of Rome, were used to assess the areas where early liberalization was possible. The Action Programmes on the Environment of 1973 and 1977 assessed the measures that could have been taken and led to the first directives in this area.

My contention is that programmes are produced in areas where there is a greater need to gather technical and political information relating to the measure at hand. Given the specialized nature and intrinsic complexity of the issues, we should expect that the Council would rely to a greater extent on the member states for implementation. A dichotomous variable will take the value of 1 if provisions or recitals in the relevant act refer to general or action programmes, the value of 0 otherwise.

Committees of member states' representatives are another important means of gathering information. Some committees are established only for the implementation of a policy and they should be conceived as constraints on executive action. This is the case for committees that oversee, using various procedures, the measures taken by the Commission. ${ }^{50}$ Other committees are set up instead to gather and exchange information, to carry out studies, to draw up reports and to support the Commission in the drafting of legislative proposals. Committees are generally established by the Council and are composed by experts seconded from national technical ministries. They can be senior officials responsible for public health, experts in agricultural or fisheries structures or in banking regulation. Some committees include representatives from trade unions and employers' associations, such as the Advisory Committee on Social Security for Migrant Workers and the Advisory Committee set up by the regulations on the movement of persons. Less frequently, the Commission establishes its own scientific advisory committee that provides relevant information for the drafting of proposals.

My contention is that the existence of these committees in an issue area is a sign of the need to gather technical and political information about specific measures. These committees deal with inherently complex and specialized issues. Therefore, we should

\footnotetext{
${ }^{49}$ Epstein and O’Halloran, Delegating Powers, pp. 211-16.

${ }^{50}$ Ballmann, Epstein and O'Halloran, 'Delegation, Comitology and the Separation of Powers in the European Union'; Franchino, 'Control of the Commission's Executive Functions', pp. 76-7; Hix, The Political System of the European Union, pp. 41-5; Pollack, 'Delegation, Agency, and Agenda Setting in the European Community', pp. 114-16.
} 
expect that the Council would take advantage of national expertise and delegate greater executive discretion to the administrations of member states. A dichotomous variable will take the value of 1 if a committee is involved in an issue area or a single act, the value of 0 otherwise.

\section{ANALYSIS OF RESULTS}

In this section, I first assess the information intensity hypotheses by comparing the average level of the discretion index of the member states and the Commission across a list of mutually exclusive and exhaustive categories. I will then examine whether the regression results corroborate the expectations of the four propositions. Given their considerably greater relevance in policy implementation, I focus on the member states first.

Tables 1 and 2 provide the first impression as to whether greater policy authority is delegated in more informationally intense issue areas. They list forty-one categories by ascending order of average discretion of the member states and of the Commission respectively.

The first result to highlight is the general bias of delegation in favour of national authorities. The member states have not been delegated powers in only one category, while the Commission has no executive discretion in seventeen categories. The most prominent ones are social security, taxation, social policy, gender equality and categories that include some legislation on the movement of persons and on company law. These results confirm the greater reliance on the technical expertise and resources of national authorities rather than on the less specialized and resourceful Commission. If the Council wants to reap agency gains, domestic institutions are the main providers.

A closer look at Table 1 provides some confirming and some disconfirming evidence. Competition rules (both general and specific to the transport sector), trade, regional policy, the system of vacancy clearance and the directives abolishing obstacles to payments are relatively simple measures with limited discretion. Company law and environmental directives, tax provisions, the regulation of professions, the directives on credit and insurance and laws on consumer protection are generally complex and require specialized knowledge. They have higher average values of the discretion index. However, it would be inappropriate to consider the organization of agricultural and fishery markets of the Community a simple area. We could also have expected greater delegation in the directives on technical standards and, especially, in the highly complex social security regulations. Equally, social policy legislation is not so complex as to justify considerable discretion.

From Table 2, it is apparent that the Commission is generally more constrained than member states. Its average discretion index across all the dataset is a mere 4.4 per cent compared to the 16.2 per cent of member states. It increases to less than 10 per cent if we exclude laws that do not delegate powers to it. Unsurprisingly, areas of extensive discretion for member states show limited or no discretion for the Commission. This is true for most of the categories with no delegation and for those at the top of the table, where the Commission reduces the Council's workload by adopting minor amendments of the specific act.

Delegation in agriculture and fishery is now explained. Here, the Council relies mostly on the Commission. The management of these markets is very complex and, importantly, is an outcome of Council's decisions, which, generally, tend to restrict national authority. As predicted, the Commission serves the Council's need of general managerial skills at 
TABLE 1 Average Discretion of Member States

\begin{tabular}{|c|c|c|}
\hline Category & $\begin{array}{l}\text { Number of } \\
\text { laws }\end{array}$ & $\begin{array}{l}\text { Average } \\
\text { discretion }\end{array}$ \\
\hline Competition: exemptions and limitation periods & 2 & $0.00 \%$ \\
\hline Merger control & 1 & $2.91 \%$ \\
\hline Competition: rules for undertakings & 8 & $3.28 \%$ \\
\hline Agriculture: financial provisions & 3 & $3.39 \%$ \\
\hline Agriculture: organization of markets & 16 & $3.72 \%$ \\
\hline Commercial policy & 9 & $4.79 \%$ \\
\hline Fishing: organization of markets & 2 & $6.01 \%$ \\
\hline Movement of persons: vacancy clearance & 3 & $6.25 \%$ \\
\hline Transport: market conditions & 4 & $6.50 \%$ \\
\hline Payments for services: liberalization & 2 & $7.64 \%$ \\
\hline Regional policy & 1 & $7.98 \%$ \\
\hline Fishing: structural policy & 3 & $8.24 \%$ \\
\hline Technical standards & 2 & $8.97 \%$ \\
\hline Transport: regulation & 2 & $10.35 \%$ \\
\hline Monetary compensation amounts & 1 & $11.11 \%$ \\
\hline Movement of capital & 3 & $11.73 \%$ \\
\hline Safety and health at work & 2 & $11.92 \%$ \\
\hline Adoption of the ECU & 2 & $12.50 \%$ \\
\hline Social security of migrant workers & 6 & $12.90 \%$ \\
\hline European Economic Interest Grouping & 1 & $15.33 \%$ \\
\hline Agriculture: structural policy & 5 & $15.71 \%$ \\
\hline Establishment and services: movement of workers & 6 & $19.75 \%$ \\
\hline Industrial and commercial property & 2 & $20.14 \%$ \\
\hline Public contracts: procedure & 4 & $20.18 \%$ \\
\hline Movement of persons: rights and derogations & 6 & $20.88 \%$ \\
\hline Consumer protection & 5 & $21.23 \%$ \\
\hline Credit and banking & 3 & $21.42 \%$ \\
\hline Insurance & 3 & $21.90 \%$ \\
\hline Qualifications and professions & 18 & $22.69 \%$ \\
\hline Equal treatment for men and women & 5 & $22.70 \%$ \\
\hline Social policy & 3 & $25.58 \%$ \\
\hline Co-operation among tax authorities & 2 & $27.56 \%$ \\
\hline Organization of working time & 1 & $28.15 \%$ \\
\hline Qualifications and professions: general system & 2 & $28.64 \%$ \\
\hline Taxation & 6 & $29.29 \%$ \\
\hline Environment & 3 & $30.92 \%$ \\
\hline Company law: safeguards & 4 & $33.06 \%$ \\
\hline Company law: accounts & 3 & $37.57 \%$ \\
\hline Education: children of migrant workers & 1 & $39.29 \%$ \\
\hline Company law: stock exchange listing & 2 & $39.50 \%$ \\
\hline International capital flows: regulation & 1 & $40.00 \%$ \\
\hline
\end{tabular}

the supranational level. Finally, information intensity cannot explain delegation of executive authority in competition, trade and regional policy.

We get a much clearer picture on delegation in the European Community if we analyse the results from regressing the discretion index on all the independent variables. They are 
TABLE 2 Average Discretion of the Commission

\begin{tabular}{lcc}
\hline \hline Category & $\begin{array}{c}\text { Number } \\
\text { of laws }\end{array}$ & $\begin{array}{c}\text { Average } \\
\text { discretion }\end{array}$ \\
\hline Credit and banking & 3 & $0.79 \%$ \\
Company law: stock exchange listing & 2 & $1.02 \%$ \\
Qualifications and professions & 18 & $1.10 \%$ \\
European Economic Interest Grouping & 1 & $1.15 \%$ \\
Consumer protection & 5 & $1.25 \%$ \\
Public contracts: procedure & 4 & $1.50 \%$ \\
Environment & 3 & $2.13 \%$ \\
Fishing: structural policy & 3 & $2.42 \%$ \\
Movement of persons: vacancy clearance & 3 & $2.61 \%$ \\
Safety and health at work & 2 & $2.61 \%$ \\
Technical standards & 2 & $2.88 \%$ \\
Co-operation among tax authorities & 2 & $3.21 \%$ \\
Movement of capital & 3 & $4.20 \%$ \\
Qualifications and professions: general system & 2 & $4.28 \%$ \\
Regional policy & 1 & $6.21 \%$ \\
Agriculture: structural policy & 5 & $6.33 \%$ \\
Transport: market conditions & 4 & $6.51 \%$ \\
Agriculture: financial provisions & 3 & $6.90 \%$ \\
Commercial policy & 9 & $7.37 \%$ \\
Merger control & 1 & $9.71 \%$ \\
Fishing: organization of markets & 2 & $10.61 \%$ \\
Agriculture: organization of markets & 16 & $14.74 \%$ \\
Monetary compensation amounts & 1 & $15.00 \%$ \\
Competition: rules for undertakings & 8 & $20.67 \%$ \\
\hline \hline
\end{tabular}

Note: There is no delegation of policy authority in the remaining seventeen categories.

shown in Table $3{ }^{51}$ The first four models test the impact of decision rules and information intensity on the discretion of Member States. The information variables have been considered first separately, then in an additive model. The combined ProgrammeCommittee variable in the fourth model takes the value of one either if legal provisions refer to action programmes or if a committee is involved in an issue area. The dependent variable in Models A and B is the value that results from subtracting the discretion of the Commission from the discretion of the member states for each act. It is a measure of relative discretion. Positive values imply that the Council relies relatively more on national administrations than on the Commission. Negative values have the opposite meaning.

The results are convincing. Most of the coefficients are significant at either 1 or 5 per cent level. The existence of a programme increases the discretion of member states by $6-7$

\footnotetext{
${ }^{51}$ Several diagnostics have been performed on the data. The $t$-statistics have been computed using White heteroscedasticity-consistent standard errors and there is no evidence of collinearity. A Ramsey RESET test reveals that the coefficient of one fitted value is significantly different from 0 in Models 2 and 4, indicating a specification error. However, inspection of the partial residual and of the fitted-versus-residual plots does not reject a linear specification of the models and the independent variables are uncorrelated with the error terms. Further, there is no evidence of omitted variables and of other specification errors in Model 1 and, importantly, in the more general Model 3 and in the Commission and relative discretion models. Finally, the first two dependent variables may both be left censored at 0 . As a final check, I have estimated normal Tobit regressions for the first five models. Results are confirmed, with minor changes. The significance of the programme variable decreases to 5 per cent in Model 1 while that of the decision variable in the Commission model increases to 1 per cent.
} 


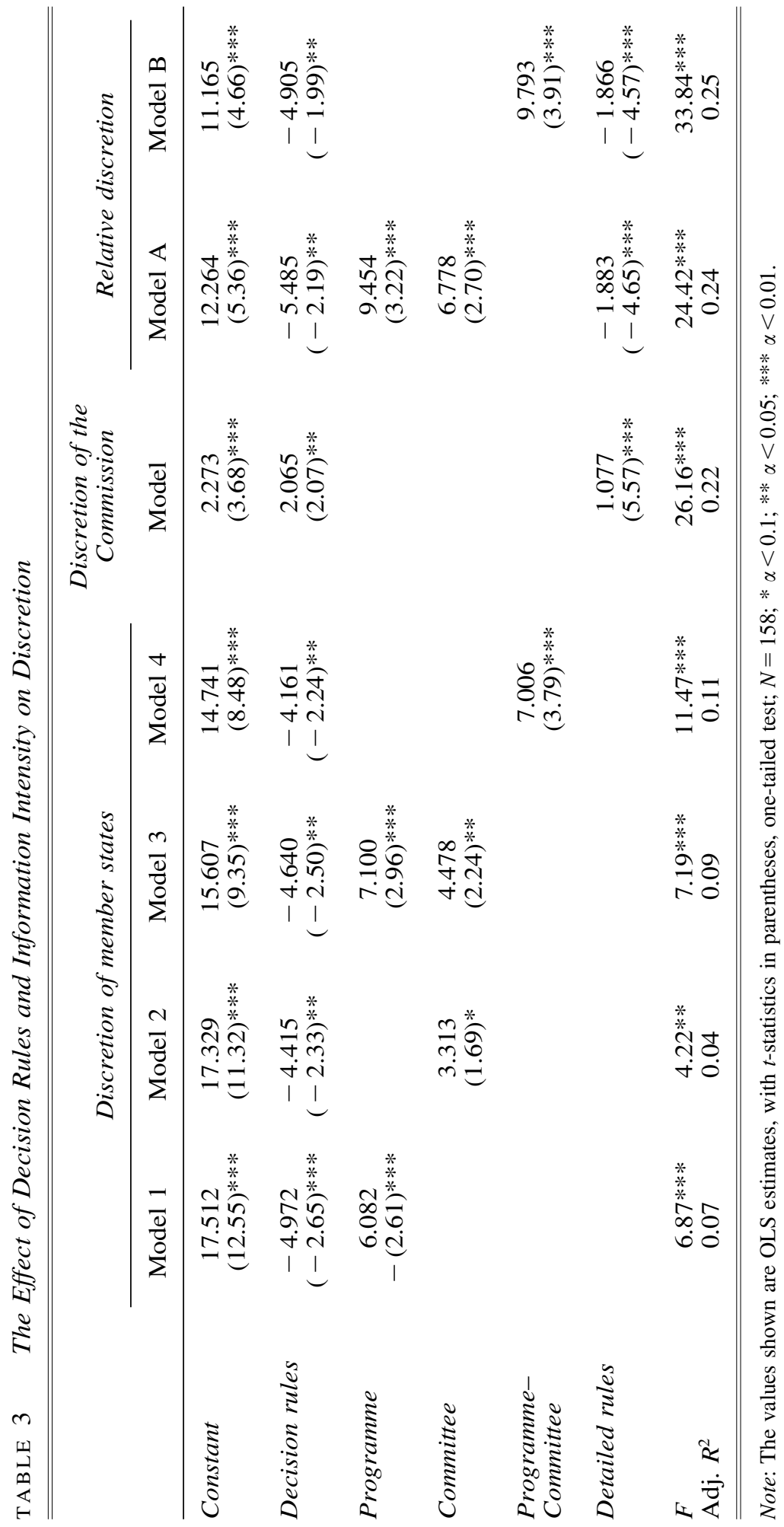


per cent. An expert committee has a greater impact when we control for more variables. Here, its effect on the discretion of member states is an increase of about 4.5 per cent. The combined variable confirms these results. The impact of these factors is even greater when the dependent variable is relative discretion. They increase the reliance on member states relative to the Commission by $7-9$ per cent. These figures are appreciable, considering the 16 per cent average national discretion and the 12 per cent average relative discretion.

Decision rules have a significant independent impact on the executive discretion of member states too. Ceteris paribus, an act adopted under unanimity delegates between 4 and 5 per cent more discretion to the governments than one adopted under qualified majority voting. It also leads to the same percentage increase of the discretion of the member state relative to that of the Commission. This result is consistent across all model specifications. Separating the effect of decision rules from that of information intensity is not straightforward, but it is reasonable to assert that unanimity explains the greater discretion in tax-related legislation, in the regulation of international capital movements, in social policy and in the directives on the right of residence. Earlier acts on the organization of agricultural markets, adopted unanimously, also delegate more policy authority than later acts adopted by qualified majority voting (compare, for instance, Regulations 19/62 and 120/67 on the market organization for cereals).

The dependent variable in the sixth column of Table 3 is the executive discretion of the Commission. As expected, the Commission enjoys an increase of 1 per cent in discretion if one major provision in the act calls for detailed rules to be adopted. This is a significant impact, given the 4.4 per cent average discretion. The signs of the coefficients for relative discretion are, as predicted, negative and significant. The Commission's discretion relative to that of national administrations increases by almost 2 per cent if one provision calls for detailed rules. The Commission's powers originate mostly from the organizational and structural aspects of the agricultural and fishery policies. But, policy authority has been delegated also for the management of monetary compensations in agriculture, the system of vacancy clearance and a 1968 system of bracket tariffs for the carriage of goods by road.

Finally, qualified majority voting significantly increases the discretion index of the Commission by 2 per cent, compared to unanimity. The significant and negative coefficients in Models A and B confirm that acts adopted according to this decision rule rely to a greater extent on the Commission than on the member states. The impact of qualified majority voting is notable especially in the legislation on competition policy, state aid to the transport sector and in some commercial policy instruments. This decision rule explains also some Commission's powers related to structural measures in the agricultural sector and in earlier acts on professional qualifications and on the movement of persons.

Interestingly, the extension of majority voting to new areas, as a result of Treaty amendments, has led to moderate increases of the Commission's executive discretion in the subsequent acts. After this extension to the legislation on public contracts, the Commission has been conferred powers to invoke, prior to the conclusion of a contract, a review procedure if infringements are manifest (Directive 89/665). Similarly, the Commission has been given additional powers to authorize and revoke protective measures in the new capital movement directive (Directive 88/361). Examples can be found in the legislation on the recognition of diplomas, on credit and banking and, arguably, on consumer protection. ${ }^{52}$

\footnotetext{
52 The shift from unanimity to majority voting has led to greater discretion, compared to prior legislation in the same area, in Directives 89/48 and 92/51 on the general system for the recognition of diplomas, in the second banking directive (Directive 89/646) and, probably, in Directive 88/378 on safety of toys.
} 
In sum, expectations are corroborated. Caution should still be exercised, however, as we cannot control directly for the impact of preference configurations.

\section{DISCUSSION AND CONCLUSION}

In a recent article, Tsebelis and Garrett have claimed that the executive discretion of the Commission is greater when new acts are adopted in the Council under unanimity rather than under qualified majority voting and, consequently, that the move to majority voting reduces the discretionary authority of the Commission. ${ }^{53}$ The results presented here suggest caution because of two shortcomings of their analysis. First, Tsebelis and Garrett disregard the executive role of national institutions. This is legitimate if a researcher wants to limit her study to the Commission. However, the policy authority enjoyed by this institution is dependent upon the attractiveness of alternative delegation options available to the Council. This article provides an initial contribution. Future works should better illustrate the Council's choice of administrative agents.

This is a more general challenge for the comparative literature on bureaucracies. Huber and Shipan suggest that an extension of their theory of delegation is to consider how bureaucratic capacity shapes legislators' choice of delegation, especially in new democracies. ${ }^{54}$ This work shows that the superior administrative resources of national administrations, compared to those of the Commission, are a potent determinant of the Council's choice of delegation in this relatively new political system. Nevertheless, a small and understaffed supranational bureaucracy is delegated powers for informational reasons. Hence, another interesting development is to assess the factors, besides constitutional provisions, that determine legislators' choice of delegation between levels of governance.

The second shortcoming of the analysis of Tsebelis and Garrett is related to the discretion of the Commission. The exercise of executive powers in policy areas under unanimity is likely to be more constrained than in areas under qualified majority voting because fewer statutory instruments are at the disposal of the Commission. For this reason, a shift from unanimity to majority voting, as in the case of capital movement legislation, is unlikely to restrain the Commission further. As a result of the shift, however, new legislation has conferred more powers and, potentially, more independence on the Commission. The causal effect, though indirect, is the opposite of what Tsebelis and Garrett expect. Deriving the Commission's discretion only from the rules of legislative override downplays the fact that the formal boundaries within which it can exercise its powers are set ex ante. Here, legislators are likely to anticipate its behaviour and the degree of ex post tinkering that a specific policy could be subject to. The executive latitude to shift the status quo becomes a crucial decision variable for them.

Incidentally, this observation should reassure scholars concerned with the democratic legitimacy of the Community policy output. The supposed deficit of democracy of the Community could widen considerably if commissioners and supranational bureaucrats could freely exploit conflict between EC legislators to implement the policy that they most prefer and, since it is so hard to replace them, get away with it. The increased heterogeneity of preferences that is likely to emerge from the future enlargement of the Community

\footnotetext{
${ }^{53}$ Tsebelis and Garrett, 'The Institutional Foundations of Intergovernmentalism and Supranationalism in the European Union', p. 383. A similar point is made by Bednar, Ferejohn and Garrett, 'The Politics of European Federalism', p. 284.

${ }^{54}$ Huber and Shipan, Deliberate Discretion? p. 229.
} 
could even be seen as alarming. This work instead suggests that the executive latitude of supranational actors is extensively predetermined by the legislators. The electoral connection of Community policies appears to be preserved and worries about the lack of democratic accountability seem misplaced.

Tsebelis has replied to this criticism and refined his argument in his recent application of the theory of legislative veto players to the autonomy of bureaucracies. First, he refers to the behavioural independence of bureaucrats, namely to the set of policy-specific measures that a bureaucrat takes to implement a policy, such as the setting of interest rates by a central bank or approving a merger by a competition authority. The focus of this study is on institutional or formal independence as derived from the reading of statutes. Secondly, Tsebelis asserts that, keeping legislation constant, namely for a given level of formal independence, the behavioural discretion of a bureaucrat increases with policy stability. ${ }^{55}$ However, in my view, a non-trivial degree of formal autonomy is a necessary condition for bureaucracies to exercise their behavioural independence. In areas where informational and distributive concerns lead legislators to confer considerable formal independence on the administrators, the threat of legislative override, as it results from the preferences of the current veto players, may determine the agent's behaviour and its independence. In effect, Tsebelis finds support for his argument in areas, such as adjudication and central banking, that are carried out by actors with considerably more formal autonomy than that of traditional bureaucracies. ${ }^{56}$ If, instead, informational and distributive concerns allow legislators to constrain administrators by adopting very restrictive statutes, the potential to be behaviourally independent is severely curtailed by the lack of formal powers and the preferences of veto players at the stage of legislative adoption should be more revealing of bureaucratic actions.

Huber and Shipan's finding that the executive is less likely to be constrained when it is harder to reach an agreement within the legislature should also be qualified. In the EC Council, it is generally harder to take unanimous decisions than to take majority ones. My results then show that a more demanding bargaining environment leads to more discretion for national authorities, but to less discretion for the Commission. In my view, this is related to the fact that the major laws selected for this work are predominantly new acts where the status quo is extensive national discretion and no powers for the Commission. This status quo is biased in favour of governments wanting to preserve national prerogatives and to constrain the Commission. In Huber and Shipan, the status quo encompasses the existing powers of the executive.$^{57}$ Hence, it is biased in favour of the legislative chamber that shares the preferences of the executive. If the other chamber is in this more beneficial position, the executive may not obtain greater discretion.

Finally, the results of this work also invite two qualifications to the literature on EC policy implementation. The similarity between the European and the existing domestic policy and the number of veto players at the execution stage are considered explanatory factors of implementation outcomes. These expectations are predominantly tested on case studies of environmental directives. ${ }^{58}$ First, these works should explicitly control for the

${ }^{55}$ Tsebelis, Veto Players, p. 236.

${ }^{56}$ Tsebelis, Veto Players, pp. 222-47.

${ }^{57}$ Discretion, their dependent variable, is the number of new words inserted in an existing statute. This implies that the executive has already some policy prerogatives (Huber and Shipan, Deliberate Discretion? pp. 143-6).

${ }^{58}$ Markus Haverland, 'National Adaptation to European Integration: The Importance of Institutional Veto Points', Journal of Public Policy, 20 (2000), 83-103; Adrienne Héritier, “"Leaders" and "Laggards" in European Clean Air Policy', in Brigitte Unger and Frans van Waarden, eds, Convergence or Diversity: Internationalization 
degree of discretion that national institutions enjoy in the implementation of each specific measure, because this is a likely determinant of the final outcome. Secondly, in acts granting considerable latitude to member states, as in environmental policy, it is relatively arduous to pin down a what exactly European policy entails and there might be a risk of mispecifying the dependent variable or the term of comparison.

For scholars of European integration, the results from this article provide a highly fragmented picture of the phenomenon. They also allow a more fine-grained understanding of how institutional choice is mapped into institutional consequences. In general terms, intergovernmentalist expectations seem validated because, if decision rules reflect underlying preferences and distributive elements, these rules produce a set of policy outcomes that broadly match member states' intent. Moreover, the scepticism about the informational advantage of the Commission is reinforced, but not entirely validated, by the much greater reliance on national administrations for policy implementation.

The approach, however, shows signs of obsolescence and this is reflected by the fact that we need to assess the impact of the European Parliament, now the second chamber in many policy areas, on delegation outcomes. Since parliamentarians face constraints that are different from those confronting Council's members, they are likely to prefer different administrative arrangements. ${ }^{59}$ Moreover, Huber and Shipan's proposition on bicameral conflict could be tested. A parliament sharing the preferences of the Commission could systematically restrict national authorities and bias delegation in favour of the supranational bureaucracy. ${ }^{60}$

(F'note continued)

and Economic Policy Response (Aldershot, Hants.: Avebury, 1995), pp. 278-306; Christoph Knill, 'European Policies: The Impact of National Administrative Traditions', Journal of Public Policy, 18 (1998), 1-28.

${ }^{59}$ Cf. Kathleen Bawn, 'Choosing Strategies to Control the Bureaucracy: Statutory Constraints, Oversight, and the Committee System', Journal of Law, Economics and Organization, 13 (1997), 101-26

${ }^{60}$ See Franchino, 'A Formal Model of Delegation in the European Union'. 


\section{APPENDIX}

The coding rules to compile my dataset follow the guidelines of Appendix D in Epstein and O'Halloran. ${ }^{61}$ In this appendix, I outline how I have adapted those rules to the EC legislation. ${ }^{62}$

\section{Counting Major Provisions: Variable $M$}

The number of major provisions in an act is counted following these rules: (1) Articles and numbered paragraphs count as separate provisions; (2) subparagraphs and indentations do not count if they merely elaborate on the previous paragraph, but they do count if they include new substantive authority; (3) unnumbered paragraphs count as separate provisions only if they are substantively distinct; (4) if a paragraph is followed by a colon and a list of elements, even if numbered, and if the elements of the lists merely elaborate on the main point of the paragraph, then the paragraph and accompanying list count as one provision; (5) I count two provisions if, even in a single sentence or a paragraph, the Commission and the member states are delegated substantively different policy authority; (6) I count only one provision if the Commission and the member states are delegated, in a sentence or a paragraph, policy authority on exactly the same issue (an example is where member states may take some measures but they need the Commission's authorization).

\section{Counting Major Provisions Delegating Powers: Variable $D_{i}$}

The definition of delegation is any major provision that gives the member states or the Commission the authority to move the policy away from the status quo. Delegation to bureaux under the auspices of and with members appointed by the Commission is delegation to the Commission. Delegation to national authorities and institutions is delegation to member states. I have only considered powers and constraints on executive action that are above and beyond those specified in the treaty. In addition to those listed by Epstein and O'Halloran, ${ }^{63} \mathrm{I}$ have regarded the following as examples of provisions delegating and not delegating powers.

Examples of what delegation to the Commission or to the member states is: the right to issue implementing regulations or directives or to take decisions with some discretion; imposition of fines and penalties; carrying out negotiations with third countries; extension of discretionary authority to new issues or economic sectors; carrying out inspections or conducting investigations or inquiries (only if they complement other powers such as those to take decisions or to impose penalties); request of information (only if it complements powers to take decisions, to carry out investigations, to tax or to impose penalties); the authorization of or the right to take measures that may alter the policy; the right to grant derogations and exemptions; transposition of provisions of directives with some discretion; extension of policy authority that member states would have otherwise relinquished as a result of adopting the measure at hand; designation of authorities and institutions.

Examples of what delegation to the Commission or to the member states is not: examination of member states' measures by the Commission but without the power to alter them or with only the faculty to issue recommendations or opinions; submission of proposals by the Commission (this is a legislative, not an executive, power); design and issuance of certificates, forms and documents; diffusing or exchanging information, setting rules for information exchange, notifying measures, ensuring professional secrecy; general calls to implement provisions; transposition of provisions of directives and obligation to take measures without discretion (these are constraints on member states); no prejudice provisions, that is provisions asserting that member states' existing prerogatives are unaffected (only if those prerogatives would have not otherwise been relinquished as a result of adopting the measure at hand); the execution, without discretion, by national authorities of measures taken by the Commission.

Most of the time, determining whether a provision delegates policy authority has been rather straightforward. In some cases, personal judgement was unavoidable but I tended to be conservative so that it was easier to reject the hypotheses.

\footnotetext{
${ }^{61}$ Epstein and O’Halloran, Delegating Powers, pp. 275-84.

${ }^{62}$ Additional information on the operationalization can be found at the website address listed in the acknowledgement.

${ }^{63}$ Epstein and O’Halloran, Delegating Powers, p. 276.
} 


\section{Categories of Procedural Constraints}

Constraints are allocated as to whether they restrain the member states' or the Commission's executive action or both. In the list below, I also refer to a set of administrative procedures, collectively called 'comitology procedures', whereby, in some cases, representatives of member states oversee the Commission's measures within implementation committees. Categories are adapted from Epstein and O'Halloran. ${ }^{64}$

The following do not need many additional comments: (1) Time Limits, but the estimated time of common measures has not been coded as a constraint; (2) Spending Limits, but the estimated total contribution of common measures has not been coded as a constraint; (3) Reporting Requirements. They include reporting to committees. Furthermore, when member states have to communicate information for the Commission to draw up a report, this has been coded as a constraint on member states too; (4) Consultation Requirements. They include a consultation procedure, called the advisory committee procedure, but the simple notification of measures has not been coded as a constraint; (5) Public Hearings; (6) Rule-making Requirements; (7) Appeals Procedures. They include provisions whereby member states must ensure that their institutions state the grounds of decisions and specify the right of appeal and of other legal remedies; (8) Exemptions, but exemptions limiting the scope of the specific act, so that national prerogatives with regard to the exempted group or class of interests are maintained, are not being coded as constraint on member states' powers.

The remaining four categories need explanation. They differ according to two principles: (a) the type of actor constraining executive action and (b) the bias and timing of control. In the first two categories, the Council limits the agent's policy authority. The difference between Legislative Action Required and Legislative Action Possible is that the former constraint is biased in favour of the revocation of an action while the latter is biased in favour of its maintenance. In the last two categories, it is a separate executive agent (i.e. the Commission, the member states or an implementation committee) that imposes constraints on the Commission or on governments. The difference between Executive Action Required and Executive Action Possible is the same as that of the Legislative Action constraints.

(9) Legislative Action Required. This is a requirement of a Council's approval prior to a Commission's or a member state's measure becoming effective. It also includes cases whereby measures, when referred to the Council, are either suspended until Council's action or, if immediately applicable, are revoked in case of Council's inaction after a set time period. It includes variant (b) of the safeguard procedure. For instance, if referred to the Council, an anti-fraud measure of a member state that affects the value added tax system could not be enacted until the Council's approval (Directive 67/228). When the Commission decides, with immediate effects, that the export of a product should be subject to an authorization, the measure is revoked if the Council does not approve it within six weeks (Regulation 2603/69).

(10) Legislative Action Possible. This category includes procedures whereby actions of the Commission or a member state are referred to the Council prior to becoming effective or whereby these measures may be referred, by the Commission or another member state, to the Council (referral may suspend the effects of the measure). The default condition in case of Council's inaction, sometimes after a set time period, is the measure taken by the Commission or the relevant state. It also includes cases of Council's direct action without a referral, but after the measures are already in force. It includes variant (a) of the safeguard procedure. For instance, Commission's measures protecting agricultural markets or on illicit practices stand if the Council does not act after a referral (e.g. Regulations 2759/75, 2641/84). Member states must hold proposed measures on liability of defective products in abeyance if there is a draft EC law, but they can put them into effect if the Council does not act within a set time period (Directive 85/374).

(11) Executive Action Required. This is a requirement that another executive agent must approve the agency's action prior to becoming effective. It includes the Commission's prior approval to member states' measures, and vice versa, and provisions asserting that the Commission can take a measure only if required by a member state. It also includes cases whereby the Commission needs the prior approval of member states' representatives of an implementation committee. This might be given by qualified majority voting (e.g. in both variants (a) and (b) of the regulatory committee procedures) or by a blocking minority (e.g. in the variant (b) of the management committee procedure). For example, Luxembourg could derogate from the first regulation on the free movement of workers only upon authorization from the Commission (Regulation 15/61). The Commission needs the approval by the relevant member state of the specific project, prior to deciding on the aid application from the guidance section of the European Agricultural Guidance

\footnotetext{
${ }^{64}$ For details on the comitology procedures, see the literature listed in $\mathrm{fn} .8$. Categories are listed in Epstein and O'Halloran, Delegating Powers, pp. 276-84, and, in the case of the Community, are analysed in greater detail in Fabio Franchino, 'Delegation and Constraints in the National Execution of the EC Policies'.
} 
and Guarantee Fund (e.g. Regulation 17/64). We can find the regulatory committee procedure in commercial policy regulations (e.g. Regulations 802-3/68) and in directives on the environment, company law and safety and health at work (e.g. Directives 76/160, 79/279 and 89/391 respectively). Variant (b) of the management committee procedure is used when the Commission has to decide whether to grant assistance from the European Regional Development Fund and when it amends the tariff nomenclature and the annexes of the general system for the recognition of diplomas (Regulations 724/75 and 2658/87, and Directive 92/51 respectively).

(12) Executive Action Possible. In this category I have coded procedures whereby measures taken by member states may be overruled, within a set time limit, by actions taken by the Commission, and vice versa. The effects of the measure can be suspended during the set time frame. It includes the variant (a) of the management committee procedure, which is used for the organization of agricultural markets and for structural measures. This procedure differs from variant (b) in the fact that the committee acts after the Commission has taken its measure. Hence, prior approval is not required. A few acts include this procedural constraint. In the anti-dumping Regulation $459 / 68$ for example, rejection of a complaint for dumping by a member state can be objected to by the Commission, and vice versa, leading to a community-wide investigation. In Directive 88/361, urgent protective measures on capital movements taken by member states can then be amended or abolished by the Commission. If a member state decides that some applicants are not allowed to choose between an adaptation period and an aptitude test with respect to a specific profession, the measure cannot be enacted for three months, during which the Commission may decide against the member state's proposal (e.g. Directive 89/48).

\section{The Constraints Index}

I employ factor analysis to assess whether more than one dimension explains the distribution of constraints and whether the categories should be weighted equally for the construction of the constraints index. ${ }^{65}$ Four factors have an eigenvalue greater than 1, but visual inspection of the scree plot suggests an initial levelling off after the second factor. The structure matrix, after an oblique rotation, shows that two factors have only one category of constraint with a unique and salient loading. Further, the coefficients of five constraints differ only marginally across factors. At least one latent variable could be considered trivial.

When the analysis is carried out with three factors, the latent variables group the constraints as follows (from the highest to the lowest loading, loadings are all positive): Factor 1: Executive Action Possible, Legislative Action Possible, Spending Limits; Factor 2: Public Hearings, Legislative Action Required, Time Limits; Factor 3: Executive Action Required, Rule-Making Requirements. Three remaining categories load on more than one factor, one has no salient loadings.

The first two latent variables group constraints that are used more frequently when policy authority is delegated to the Commission. Pearson correlation coefficients between these constraints and the Commission's delegation ratios for each law are positive and significant, while some constraints correlate negatively with the member states' delegation ratios. Patterns of correlation with the independent variables developed for this article confirm this result. The difference between the two factors is a greater significance of the Pearson coefficients in the first latent variable. I have found no other empirical evidence distinguishing them. The third factor groups categories of constraints that either do not correlate with any delegation ratio and independent variable or correlate positively with the member states' delegation ratios.

The issue of weighting should be considered in two steps. First, we should assess whether the dimensions should be weighted differently. Clearly, the stringency of a constraint is independent from the executive actor. If the Council requires its prior approval for a measure, it would be inappropriate to consider this constraint differently depending on whether the Commission or a member state takes the measure in question. Factors are therefore weighted equally. The second issue is to evaluate whether the categories of constraints within each factor should be weighted differently. The standard deviations of the factor loadings are moderately small $(0.123,0.099$ and 0.153 for the three latent variables respectively). Equal weighting seems appropriate in this case too.

\footnotetext{
${ }^{65}$ For selection and interpretation of the factors, I follow the guidelines of Richard L. Gorsuch, Factor Analysis (Hillsdale, N.J.: Lawrence Erlbaum, 1983), pp. 169-71, 206-12.
} 
